\title{
Review Article \\ Selection of Diagnostic Cutoffs for Murine Typhus IgM and IgG Immunofluorescence Assay: A Systematic Review
}

\author{
Sandhya Dhawan, ${ }^{1}$ Matthew T. Robinson, ${ }^{2,3}$ John Stenos, ${ }^{4}$ Stephen R. Graves, ${ }^{4}$ Tri Wangrangsimakul, ${ }^{1,2}$ Paul N. Newton, ${ }^{2,3}$ \\ Nicholas P. J. Day, ${ }^{1,2}$ and Stuart D. Blacksell ${ }^{1,2,3 *}$ \\ ${ }^{1}$ Mahidol Oxford Tropical Medicine Research Unit, Faculty of Tropical Medicine, Mahidol University, Bangkok, Thailand; ${ }^{2}$ Centre for \\ Tropical Medicine and Global Health, Nuffield Department of Medicine, University of Oxford, Oxford, United Kingdom; ${ }^{3}$ Lao-Oxford-Mahosot \\ Hospital-Wellcome Trust Research Unit (LOMWRU), Mahosot Hospital, Vientiane, Lao People's Democratic Republic; ${ }^{4}$ Australian Rickettsial \\ Reference Laboratory, University Hospital Geelong, Geelong, Australia
}

\begin{abstract}
Murine typhus is a neglected but widespread infectious disease that results in acute fever. The immunofluorescence assay (IFA) is the "gold standard" to identify lgM or lgG antibodies, although there is a lack of standardization in methodologies. The objective of this review is to summarize 1) the differences in published methodologies, 2) the diagnostic cutoff titers, and 3) the justification of diagnostic cutoffs. Searches were performed by combining the following search terms: "murine typhus," "rickettsia typhi," "immunofluorescence," "IFA," and "serologic" with restrictions (i.e., "rickettsia typhi" or "murine typhus," and "IFA" or "immunofluorescence," or "serologic"). The search identified 78 studies that used IFA or immunoperoxidase assay (IIP) antibody cutoffs to diagnose murine typhus, 39 of which were case series. Overall, 45 studies $(57.7 \%)$ provided little to no rationale as to how the cutoff was derived. Variation was seen locally in the cutoff titers used, but a 4-fold or greater increase was often applied. The cutoffs varied depending on the antibody target. No consensus was observed in establishing a cutoff, or for a single-value diagnostic cutoff. In conclusion, there is a lack of consensus in the establishment of a single-value cutoff. Further studies will need to be executed at each distinct geographic location to identify region-specific cutoffs, while also considering background antibody levels to distinguish between healthy and infected patients.
\end{abstract}

\section{INTRODUCTION}

Murine typhus is a neglected infectious disease caused by Rickettsia typhi, a Gram-negative, obligate intracellular bacterium. Rickettsia typhi is primarily transmitted by Xenopsylla cheopis, the rat flea. ${ }^{1}$ Commensal rats (most commonly Rattus rattus and Rattus norvegicus) are the natural animal reservoir of the disease. Infection in humans occurs either through inoculation of infected flea feces into bite wounds or by inhalation of aerosolized flea feces. ${ }^{2-4}$

Given that other febrile illnesses, such as dengue, leptospirosis, and typhoid, have similar clinical manifestations to murine typhus, ${ }^{3,5}$ laboratory tests are essential to differentiate murine typhus from other causes of undifferentiated fever. Serological methods are commonly used to diagnose murine typhus because of their simplicity and cost-effectiveness. ${ }^{6,7}$ The indirect immunofluorescence assay (IFA) is considered the "gold standard" and reference technique for diagnosing murine typhus in most research laboratories. ${ }^{1-3,8}$ Immunofluorescence assay identification of $\lg M$ and $\lg G$ antibodies provides definitive and accurate evidence of exposure. ${ }^{2,9,10}$ The immunoperoxidase assay (IIP) is an alternative to IFA and obtains results that have a similar sensitivity and specificity. ${ }^{11}$

The diagnostic accuracy of IFA is subjective and reliant on methodological and patient factors. Despite being the current reference and standard technique, there is little consensus on the standardization of the IFA methodology. Variable methodological factors include the antigenic strains used and antibody isotype targeted, as well as the diagnostic cutoffs used. Therefore, to guarantee accuracy of diagnosis, standardized methodologies and locally authenticated positivity cutoff

*Address correspondence to Stuart Blacksell, Mahidol Oxford Tropical Medicine Research Unit, Faculty of Tropical Medicine, Mahidol University, 420/6 Rajvithi Rd., Bangkok 10400, Thailand. E-mail: stuart@tropmedres.ac limits for diagnostic and epidemiological purposes are required.

This review aims to summarize 1) the differences in published IFA methodologies, 2) the diagnostic cutoff titers used for a positive murine typhus diagnosis, and 3) the justification of these diagnostic cutoffs.

\section{METHODS}

Search strategy and eligibility criteria. A systematic review was performed. Searches were performed by one author (S. D.) on the PubMed electronic database by combining the following search terms: "murine typhus," "rickettsia typhi," "immunofluorescence," "IFA," and "serologic" with restrictions (i.e., "rickettsia typhi" or "murine typhus," and "IFA" or "immunofluorescence," or "serologic"). The search was limited to articles that had been published in or could be successfully translated to English, until July 2018. First, the titles and abstracts were screened for applicability. Then, full text of relevant articles were examined to establish eligibility. Diagnostic accuracy studies, case series, and cross-sectional studies using IFA/IIP to diagnose murine typhus were included. We excluded case reports, nonhuman studies, and studies investigating other serological tests (i.e., CF, OX-19, and ELISA). Reference lists of the selected studies were also screened to identify further studies.

Data extraction and analysis. Data were extracted by one author (S. D.), and where the information was unclear, a second researcher was consulted (S. D. B.). Details of the location, sample size, study design, reference test, positivity cutoff titer, antibody target, antigenic strain, positivity criteria, and justification for positive cutoff titer were compiled into summary tables. The studies were grouped according to the study design (diagnostic accuracy study, case series, or crosssectional study) and geographical location. The data were summarized using a narrative synthesis. We did not evaluate 
intricacies of individual IFA protocols but instead focused on the broader issues such as the methodology used to derive diagnostic cutoffs.

\section{RESULTS}

Summary of studies. Study types. Of the total of 78 studies included in this review (Table 3), 39 (49.4\%) were case series, 34 (43\%) were cross-sectional studies, and five (6.33\%) were diagnostic accuracy studies (Supplemental Table 3, Tables 1 and 2).

Patient and geographic details. The study year of included articles ranged from 1977 to 2018 . The total number of cases analyzed was 392,756. Geographically, the studies were conducted on patients from Spain $(12.8 \%, n=10)$, Taiwan $(9.0 \%, n=7)$, United States $(7.7 \%, n=6)$, Lao PDR $(6.4 \%, n=$ $5)$, Tunisia $(6.4 \%, n=5)$, Thailand $(6.4 \%, n=5)$, and Greece $(6.4 \%, n=5)$. The remaining study populations were recruited from American Samoa, Australia, Brazil, China, Colombia, Croatia, Cyprus, Djibouti, France, Germany, Indonesia, Israel, Madagascar, Malaysia, Malta, Morocco, Nepal, New Zealand, Singapore, Sri Lanka, Tanzania, Vietnam, and Zambia (Table 3). One study conducted in Marseilles, France, investigated travelers returning from Africa and Southeast Asia. ${ }^{12}$ Two studies examined serum samples from three different countries. ${ }^{8,13}$

Immunofluorescence assay methodology. Source. More than half of the studies did not specify the source of the IFA kits $(57.7 \%, n=45)$. Thirty-two studies (41\%) specified the source of the IFA kits, of which BioMérieux (BioMérieux Ltd., Marcyl'Étoile, Lyon, France) was the most common source used in nine studies $(27.3 \%, 9 / 33)$. Five studies $(15.2 \%, 5 / 33)$ used IFA methods developed by the Australian Rickettsial Reference Laboratory (ARRL), whereas five used IFA methods developed by the U.S. Army Medical Research Unit, Malaysia.

Antibody isotype. Of the 78 studies evaluated, 61 stated the target antibody isotype, whereas 17 studies $(21.8 \%, 17 / 78)$ did not specify the antibody isotype being targeted. The majority of the studies tested for both $\lg M$ and $\lg G(37.7 \%, 23 / 61)$ against $R$. typhi. Eighteen studies $(29.5 \%, 18 / 61)$ tested exclusively for IgG, whereas nine studies $(14.8 \%, 9 / 61)$ tested solely for IgM. Ten studies $(16.4 \%, 10 / 61)$ performed whole antibody testing (both $\lg M$ and $\lg G$ ). In one case $(1.6 \%, 1 / 61)$, $\lg \mathrm{M}, \lg \mathrm{G}$, and $\lg \mathrm{A}$ were tested for. ${ }^{14}$

Antigenic composition. A narrow range of antigens were used in the IFAs examined. More than half of the studies did not specify the antigenic strain used $(67.9 \%, n=53)$; of the 24 studies that did, the Wilmington strain was the most numerous-in 21 studies $(87.5 \%, 21 / 24)$. Of the nine studies using BioMérieux IFAs, eight studies (88.9\%, 8/9) did not specify the antigenic strain used, whereas one $(11.1 \%, 1 / 9)$ used the Moroccan strain. ${ }^{15}$ Five studies used ARRL developed IFAs, of which $3(60 \%, 3 / 5)$ used the Wilmington strain and two $(40 \%, 2 / 5)$ did not specify the antigenic strain used. Five studies used IFAs developed by the U.S. Army Medical Research Unit, Malaysia, of which two $(40 \%, 2 / 5)$ used the Wilmington strain and three $(60 \%, 3 / 5)$ did not specify the strain used.

Cutoffs used and methodology for selecting cutoffs. Diagnostic cutoffs. All studies show considerable variation between the cutoffs (Figure 1). Diagnostic cutoffs for IgM ranged from $\geq 1: 32$ to $\geq 1: 400$, and IgG cutoffs ranged from $\geq 1: 16$ to $\geq 1: 960$ (Figure $1 B$ and $C$ ). From the 78 studies included, the most common cutoffs noted for IgM were $\geq 1: 64$ $(10.2 \%, n=8)$, followed by $\mathrm{a} \geq 4$-fold increase $(6.4 \%, n=5)$ in paired samples, and $\geq 1: 80(6.4 \%, n=5)$ (Figure 1B). The most common cutoffs noted for IgG were a $\geq 4$-fold increase $(15.4 \%, n=12)$ in paired samples, followed by $\geq 1: 128(9.0 \%$, $n=7)$, and $\geq 1: 64(5.1 \%, n=4)$ (Figure 1C). Of these studies, 23 $(29.5 \%, 23 / 78)$ stated cutoffs for IgG and IgM. Eighteen of them $(78.3 \%, 18 / 23)$ established higher cutoff values for IgG than IgM. In four cases $(17.4 \%, 4 / 23)$, the cutoff value for IgM was higher, whereas in one case $(4.4 \%, 1 / 23)$, identical cutoff values were applied to both isotypes. Ten $(12.8 \%, 10 / 78)$ studies targeted both IgG and IgM isotypes. The majority of these studies $(50 \%, 5 / 10)$ used a 4 -fold or greater increase in titers in paired samples as a diagnostic cutoff. There was a considerable variation in choice of single-titer cutoffs for whole antibody targeting (Table 4).

Criteria for selecting cutoffs. All 78 studies reported at least one positivity criterion. Differentiating by study design, of the 39 case series, a single-titer cutoff was the most commonly used criterion $(53.8 \%, n=21)$, with the cutoff ranging from $\geq 1: 25$ to $\geq 1: 960$ with the majority $(17.9 \%, 7 / 39)$ using a titer of $\geq 1: 64$ (Supplemental Table 3). Four case series $(10.3 \%$, 4/39) exclusively used $a \geq 4$-fold increase in antibodies in paired samples, whereas $13(33.3 \%, 13 / 39)$ used this criterion in conjunction with a fixed titer cutoff (Supplemental Table 3). Of the 34 cross-sectional studies, the majority $(70.6 \%, n=24)$ used a single-titer cutoff to determine positivity, the cutoff ranging from $\geq 1: 16$ to $\geq 1: 4000$ with the majority $(23.5 \%, 8 / 34)$ using a titer of $\geq 1: 64$ (Table 1$)$. Only one study $(2.9 \%, 1 / 34)$ used exclusively $\mathrm{a} \geq 4$-fold increase in antibodies as a criterion, whereas eight $(23.5 \%, 8 / 34)$ used this criterion together with a fixed titer cutoff (Table 3). Of the five diagnostic accuracy studies, four $(80 \%, 4 / 5)$ used a single positivity cutoff titer, ranging from $\geq 1: 100$ to $\geq 1: 400$ (Table 2 ).

Differentiating by country (Table 3 ), a single-titer cutoff was the preferred method of diagnosis in Cyprus, Greece, Spain, and Tunisia, whereas in Indonesia, Lao PDR, Sri Lanka, Thailand, and United States, a single-titer cutoff in conjunction with $a \geq 4$-fold increase in titers was preferred. Only in Taiwan was a solely $\geq 4$-fold increase in titers as a diagnostic cutoff preferred.

Justification for selecting cutoffs. Of a total of 78 studies, only $33(42.3 \%, 33 / 78)$ justified the method to determine their diagnostic cutoff, whereas $45(57.7 \%, 45 / 78)$ studies provided no clear explanation for the cutoff value used. Of the 33 studies with reasons for their selected cutoff values, $28(84.8 \%, 28 / 33)$ justified it by citing a supporting previous study. The most frequently cited seropositivity criteria study was that of $\mathrm{La}$ Scola et al. ${ }^{6}(14.3 \%, 4 / 28)$. Other commonly cited studies were Blacksell et al., ${ }^{16}$ Coleman et al., ${ }^{17}$ and Hernandez et al. ${ }^{18}$ A further 19 references for justification ${ }^{19-36}$ were cited by 18 studies. Three studies $(9.1 \%, 3 / 33)$ used "manufacturers specifications" as a justification for their cutoff values, ${ }^{37-39}$ whereas one study $(3.0 \%, 1 / 33)$ followed the "WHO Collaborating Centre procedure" to determine their cutoff. ${ }^{40}$

\section{DISCUSSION}

To classify confirmed cases and to ensure appropriate patient management, the application of accurate diagnostic cutoffs is necessary for murine typhus. This review has found 
DIAGNOSTIC CUTOFFS FOR MURINE TYPHUS

TABLE 1

Summary of cross-sectional studies

\begin{tabular}{|c|c|c|c|c|c|c|c|c|c|}
\hline Country & Type of test & Source of assay & Total cases & Antigenic strain & $\begin{array}{l}\text { Positivity } \\
\text { cutoff titer }\end{array}$ & $\begin{array}{c}\text { Antibody } \\
\text { target }\end{array}$ & $\begin{array}{l}\text { Positivity } \\
\text { criteria }\end{array}$ & Cutoff justification & Reference \\
\hline $\begin{array}{r}\text { American } \\
\text { Samoa }\end{array}$ & IFA & NA & 197 & NA & $1: 50$ & $\lg G$ & Single titer & NA & 44 \\
\hline Brazil & IFA & NA & 437 & NA & $\begin{array}{c}>1: 64 \\
\geq 4 \text {-fold increase } \\
1: 64\end{array}$ & $\begin{array}{l}\lg M \\
\lg M \\
\lg G\end{array}$ & $\begin{array}{l}\text { Both } \\
\text { Single titer }\end{array}$ & NA & 45 \\
\hline Croatia & IFA & $\begin{array}{l}\text { Virus Reference } \\
\quad \text { Laboratory, London, UK }\end{array}$ & 425 & NA & $\geq 1: 16$ & $\lg G$ & Single titer & NA & 46 \\
\hline Djibouti & IFA & NA & 12,300 & NA & $\begin{array}{l}\geq 1: 80 \\
\geq 4 \text {-fold increase }\end{array}$ & $\begin{array}{l}\text { NA } \\
\text { NA }\end{array}$ & Both & 36 & 47 \\
\hline Greece & IFA & $\begin{array}{l}\text { Biomerieux, Marcy } \\
\text { l'Etoile, Lyon, France }\end{array}$ & 1,584 & NA & $\geq 1: 64$ & $\lg G$ & Single titer & NA & 48 \\
\hline Indonesia & IFA & NA & 142 & NA & $\geq 1: 80$ & NA & Single titer & 32,35 & 49 \\
\hline Lao PDR & IFA & NA & 427 & NA & $\begin{array}{c}>1: 64 \\
\geq 4 \text {-fold increase } \\
>1: 128\end{array}$ & $\begin{array}{l}\lg M \\
\lg M \text { and } \\
\lg G \\
\lg G\end{array}$ & Both & 6,31 & 50 \\
\hline Madagascar & IFA & NA & 31 & $\mathrm{NA}$ & $1: 4000$ & $\lg G$ & Single titer & NA & 51 \\
\hline Malaysia & IFA & NA & 1596 & Wilmington & $\geq 1: 50$ & Whole & Single titer & 52 & 53 \\
\hline Morocco & IFA & $\begin{array}{l}\text { Biomerieux, Marcy } \\
\text { l'Etoile, Lyon, France }\end{array}$ & 300 & $\begin{array}{l}\text { Moroccan } \\
\text { strain }\end{array}$ & $\geq 1: 32$ & NA & Single titer & 20,21 & 15 \\
\hline Nepal & IFA & NA & 103 & Wilmington & $\begin{array}{c}\geq 1: 400 \\
\geq 4 \text {-fold increase }\end{array}$ & $\begin{array}{l}\lg M \\
\lg M\end{array}$ & Both & 17 & 54 \\
\hline New Zealand & IFA & $\begin{array}{l}\text { Australian Rickettsial } \\
\text { Reference } \\
\text { Laboratory, Victoria, } \\
\text { Australia }\end{array}$ & 989 & NA & $\geq 1: 128$ & $\lg G$ & Single titer & $\begin{array}{l}\text { Manufacturer's } \\
\text { specifications }\end{array}$ & 39 \\
\hline Singapore & IIP & $\begin{array}{l}\text { U.S. Army Medical } \\
\text { Research Unit, Malaysia }\end{array}$ & 35 & NA & $\begin{array}{c}\geq 1: 1600 \\
\geq 1: 400 \\
\geq 4 \text {-fold increase }\end{array}$ & $\begin{array}{l}\lg G \\
\lg G \\
\lg G\end{array}$ & Both & $\begin{array}{l}\text { Manufacturer's } \\
\text { specifications }\end{array}$ & 38 \\
\hline \multirow[t]{10}{*}{ Spain } & $\begin{array}{l}\text { IFA } \\
\text { IFA }\end{array}$ & $\begin{array}{c}\text { NA } \\
\text { Biomerieux, Marcy } \\
\text { l'Etoile, Lyon, France }\end{array}$ & $\begin{array}{l}341 \\
662\end{array}$ & $\begin{array}{l}\text { NA } \\
\text { NA }\end{array}$ & $\begin{array}{c}1: 40-1: 160 \\
\geq 1: 80\end{array}$ & $\begin{array}{l}\text { NA } \\
\lg G\end{array}$ & $\begin{array}{l}\text { Range } \\
\text { Single titer }\end{array}$ & $\begin{array}{c}\text { NA } \\
\text { Manufacturer's } \\
\text { specifications }\end{array}$ & $\begin{array}{l}55 \\
37\end{array}$ \\
\hline & IFA & $\begin{array}{l}\text { Focus technologies, } \\
\text { Cypress, CA }\end{array}$ & 734 & NA & $\geq 1: 64$ & $\lg \mathrm{M}$ & Both & NA & 56 \\
\hline & & & & & $\begin{array}{l}\geq 4 \text {-fold increase } \\
\quad \geq 1: 64\end{array}$ & $\begin{array}{l}\lg M \\
\text { NA }\end{array}$ & & & \\
\hline & IFA & NA & 104 & NA & $\begin{array}{c}\geq 1: 512 \\
\geq 4 \text {-fold increase }\end{array}$ & $\begin{array}{l}\lg G \\
\lg G\end{array}$ & Both & NA & 57 \\
\hline & IFA & NA & 640 & Wilmington & $\begin{array}{l}\geq 1: 128 \\
\geq 1: 40\end{array}$ & $\begin{array}{l}\lg G \\
\lg M, \lg G,\end{array}$ & $\begin{array}{l}\text { Single titer } \\
\text { Single titer }\end{array}$ & NA & 14 \\
\hline & IFA & $\begin{array}{l}\text { MRL Diagnostics, } \\
\text { Cypress, CA }\end{array}$ & 217 & NA & $\geq 1: 40$ & $\lg G$ & Single titer & NA & 58 \\
\hline & IFA & NA & 400 & NA & $1: 40$ & NA & Single titer & NA & 59 \\
\hline & IFA & $\begin{array}{l}\text { Focus technologies, } \\
\text { Cypress, CA }\end{array}$ & 504 & $\begin{array}{l}\text { ref no. } \\
\text { IF0100 }\end{array}$ & $\geq 1: 64$ & NA & Single titer & NA & 60 \\
\hline & IFA & NA & 383 & Wilmington & $\geq 1: 80$ & $\lg G$ & Single titer & NA & 61 \\
\hline & IFA & $\begin{array}{l}\text { Biomerieux, Marcy } \\
\text { I'Etoile, Lyon, France }\end{array}$ & 356,266 & NA & $\geq 1: 40$ & NA & Single titer & NA & 62 \\
\hline \multirow[t]{3}{*}{ Taiwan } & IFA & $\begin{array}{l}\text { Taiwan CDC, Taipei, } \\
\text { Taiwan }\end{array}$ & 226 & NA & $\geq 1: 80$ & $\lg M$ & Single titer & NA & 63 \\
\hline & & & & & $\geq 4$-fold increase & $\lg G$ & Only 4-fold & & \\
\hline & IFA & $\begin{array}{l}\text { Taiwan CDC, Taipei, } \\
\text { Taiwan }\end{array}$ & 1420 & NA & $\geq 4$-fold increase & NA & Only 4-fold & NA & 64 \\
\hline \multirow[t]{2}{*}{ Tanzania } & IFA & NA & 870 & Wilmington & $\begin{array}{c}\geq 1: 64 \\
\geq 4 \text {-fold increase }\end{array}$ & $\begin{array}{l}\lg M \\
\lg G\end{array}$ & $\begin{array}{l}\text { Single titer } \\
\text { Only 4-fold }\end{array}$ & NA & 65 \\
\hline & IFA & NA & 150 & $\begin{array}{l}\text { ATCC } \\
\text { AZ332 }\end{array}$ & $>1: 50$ & Whole & Single titer & 21 & 66 \\
\hline \multirow[t]{3}{*}{ Tunisia } & IFA & NA & 500 & NA & $\geq 1: 32$ & Whole & Single titer & 20 & 67 \\
\hline & IFA & NA & 47 & NA & $\geq 1: 32$ & $\lg \mathrm{M}$ & Single titer & NA & 68 \\
\hline & IFA & NA & 1024 & NA & $\begin{array}{l}>1: 128 \\
\geq 1: 32\end{array}$ & $\begin{array}{l}\lg G \\
\lg M\end{array}$ & $\begin{array}{l}\text { Single titer } \\
\text { Single titer }\end{array}$ & NA & 69 \\
\hline United & IFA & NA & 204 & NA & $\geq 1: 64$ & $\lg G$ & Single titer & NA & 70 \\
\hline States & IFA & $\begin{array}{l}\text { Focus technologies, } \\
\text { Cypress, CA }\end{array}$ & 152 & NA & $\geq 1: 64$ & $\lg G$ & Single titer & NA & 71 \\
\hline Vietnam & IFA & In-house & 193 & Wilmington & $\begin{array}{c}1: 400 \\
\geq 4 \text {-fold increase }\end{array}$ & $\begin{array}{l}\lg G \\
\lg G\end{array}$ & Both & 54 & 72 \\
\hline Zambia & IFA & NA & 377 & Wilmington & $\begin{array}{l}\geq 1: 32 \\
\geq 1: 64\end{array}$ & $\begin{array}{l}\text { lgM } \\
\text { Whole }\end{array}$ & $\begin{array}{l}\text { Single titer } \\
\text { Single titer }\end{array}$ & NA & 73 \\
\hline
\end{tabular}


TABLE 2

Summary of diagnostic accuracy studies

\begin{tabular}{|c|c|c|c|c|c|c|c|c|c|}
\hline Country & $\begin{array}{c}\text { Type of } \\
\text { test }\end{array}$ & Source of assay & $\begin{array}{l}\text { Total } \\
\text { cases }\end{array}$ & Antigenic strain & Positivity cutoff titer & Antibody target & Positivity criteria & $\begin{array}{c}\text { Cutoff } \\
\text { justification }\end{array}$ & Reference \\
\hline Israel & IFA & NA & 23 & NA & $\geq 1: 100$ & Whole & Single titer & NA & 74 \\
\hline \multirow[t]{2}{*}{ Lao PDR } & IFA & $\begin{array}{l}\text { Australian Rickettsial } \\
\text { Reference Laboratory, } \\
\text { Victoria, Australia }\end{array}$ & 1030 & Wilmington & $\geq 1: 400$ & $\lg M$ & Single titer & 17 & 75 \\
\hline & IFA & - & 50 & Wilmington & $\begin{array}{c}\geq 4 \text {-fold increase } \\
\geq 1: 400 \\
\geq 4 \text {-fold increase }\end{array}$ & $\begin{array}{l}\lg M \text { and } \lg G \\
\text { Whole } \\
\text { Whole }\end{array}$ & $\begin{array}{l}\text { Only 4-fold } \\
\text { Both }\end{array}$ & 17 & 76 \\
\hline $\begin{array}{l}\text { Peru, United States, } \\
\text { Somalia, and } \\
\text { Indonesia }\end{array}$ & IFA & NA & 60 & Wilmington & $\geq 1: 128$ & $\lg G$ & Single titer & NA & 8 \\
\hline $\begin{array}{l}\text { Russia, Peru, } \\
\text { and Burundi }\end{array}$ & IFA & $\begin{array}{l}\text { Dynatech Laboratories } \\
\text { Ltd, UK }\end{array}$ & 308 & Wilmington & $\geq 1: 128$ & $\lg G$ & Single titer & 25,26 & 13 \\
\hline
\end{tabular}

that there was a major lack of consensus regarding methodologies, application, and IFA/IIP positivity cutoffs used for the diagnosis of murine typhus infections; the reasons for which are manifold and need further investigation and standardization.

In many cases $(57.7 \%, 45 / 78)$, a clear justification for the cutoff used was not provided, and it is likely that differences in approach evolved naturally based on local antigenic strains and the pretest odds of disease depending on the local level of murine typhus endemicity. This variation raises questions about which, if any, IFA positivity cutoff is most appropriate for the diagnosis of acute murine typhus infection.

Of the five diagnostic accuracy studies, the majority $(60 \%$, $3 / 5$ ) provided sufficient justification for the positivity cutoff titer used. Although there was a lack of consensus in terms of the source used for the reference test, a single positivity cutoff

TABLE 3

Summary of cutoff titer positivity criteria and antibody isotype described in selected studies

\begin{tabular}{|c|c|c|c|c|c|c|c|c|c|c|c|}
\hline & \multicolumn{5}{|c|}{ Positivity cutoff titer criteria } & \multicolumn{6}{|c|}{ Antibody target (n studies) } \\
\hline & Single titer & Both & Only 4-fold & Range & Total & $\lg M$ & $\lg G$ & Whole & $\operatorname{lgM} / \operatorname{lgG}$ & Not stated & Isotype total \\
\hline \multicolumn{12}{|l|}{ Country } \\
\hline American Samoa & 1 & & & & 1 & & 1 & & & & 1 \\
\hline Australia & 1 & & & & 1 & & & & 1 & & 1 \\
\hline Brazil & 1 & 1 & & & 2 & & & & 1 & & 1 \\
\hline China & 2 & & & & 2 & & & & 1 & & 1 \\
\hline Colombia & 1 & & 1 & & 2 & & & & 1 & & 1 \\
\hline Croatia & 1 & & 1 & & 2 & & 1 & 1 & & & 2 \\
\hline Cyprus & 4 & & & & 4 & & & & 2 & & 2 \\
\hline Djibouti & & 1 & & & 1 & & & & & 1 & 1 \\
\hline France & 3 & & & & 3 & & & & 1 & 1 & 2 \\
\hline Germany & 1 & & & & 1 & & 1 & & & & 1 \\
\hline Greece & 5 & 3 & & & 8 & 1 & 1 & & 2 & 1 & 5 \\
\hline Indonesia & 1 & 3 & & & 4 & & & & 1 & 1 & 2 \\
\hline Israel & 2 & & & & 2 & 1 & & 1 & & & 2 \\
\hline Lao PDR & 1 & 2 & 2 & & 5 & & & 3 & 2 & & 5 \\
\hline Madagascar & 1 & & & & 1 & & 1 & & & & 1 \\
\hline Malaysia & 1 & & & & 1 & & 1 & 1 & & & 2 \\
\hline Malta & 1 & & & & 1 & 1 & & & & & 1 \\
\hline Morocco & 1 & & & & 1 & & & & & 1 & 1 \\
\hline Nepal & 1 & 1 & 1 & & 3 & 1 & & & 1 & & 2 \\
\hline New Zealand & 1 & & & & 1 & & 1 & & & & 1 \\
\hline Singapore & & 1 & & & 1 & & 1 & & & & 1 \\
\hline Spain & 8 & 2 & & 1 & 11 & 1 & 4 & & & 4 & 9 \\
\hline Sri Lanka & 1 & 3 & & 1 & 5 & 1 & & & 1 & & 2 \\
\hline Taiwan & 6 & & 7 & & 13 & & & & 6 & 1 & 7 \\
\hline Tanzania & 2 & & 1 & & 3 & & & 1 & 1 & & 2 \\
\hline Thailand & & 5 & & & 5 & & & 1 & & 4 & 5 \\
\hline Tunisia & 6 & 3 & & & 9 & 2 & & 1 & 2 & 1 & 6 \\
\hline United States & 2 & 4 & & & 6 & & 3 & & 1 & 2 & 6 \\
\hline Vietnam & & 1 & & & 1 & & 1 & & & & 1 \\
\hline Zambia & 2 & & & & 2 & & & 1 & & & 1 \\
\hline Total & 57 & 30 & 13 & 2 & $102^{*}$ & 8 & 16 & 10 & 24 & 17 & $75 \dagger$ \\
\hline \multicolumn{12}{|l|}{ Study design } \\
\hline Case series & 21 & 13 & 4 & 1 & 39 & 6 & 3 & 4 & 17 & 9 & 39 \\
\hline Cross-sectional studies & 24 & 8 & 1 & 1 & 34 & 3 & 13 & 4 & 6 & 8 & 34 \\
\hline Diagnostic accuracy studies & 4 & 1 & & & 5 & & 2 & 2 & 1 & & 5 \\
\hline Total & 49 & 22 & 5 & 2 & 78 & 9 & 18 & 10 & 24 & 17 & 78 \\
\hline
\end{tabular}

* Some studies provided different positivity criteria for $\lg M$ and $\lg G$.

†Three studies were not included as they examined murine typhus in travelers from various countries. 
A

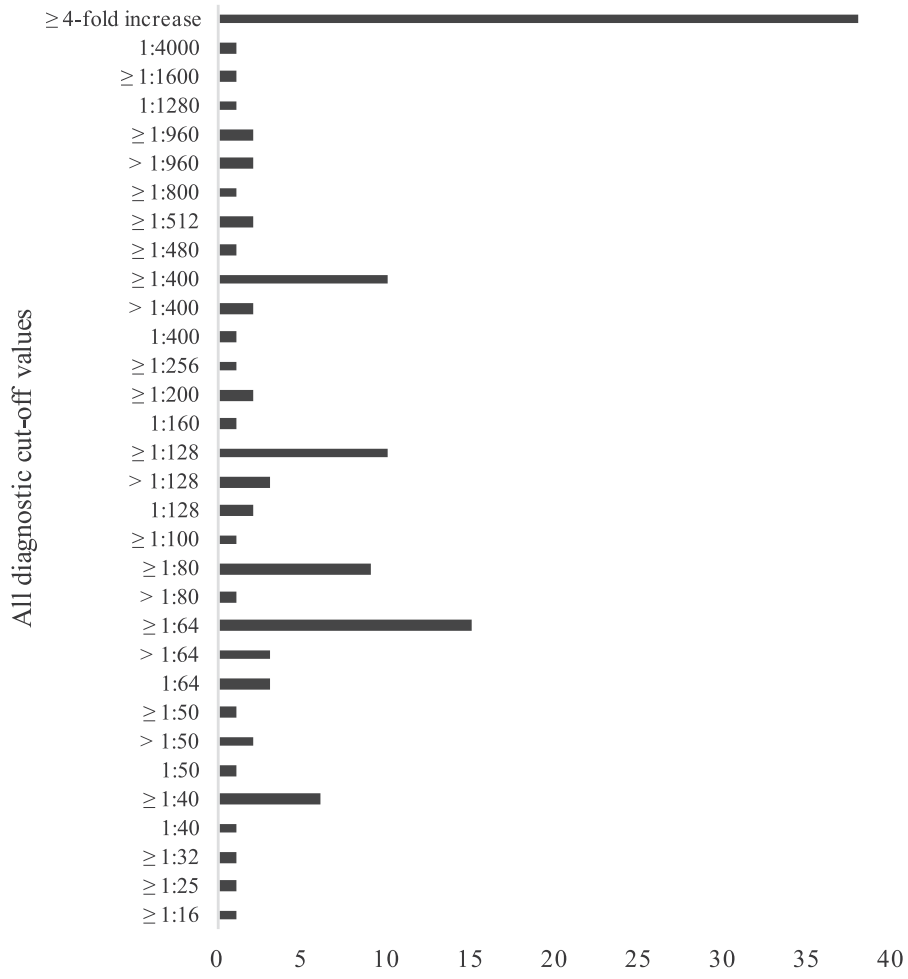

B

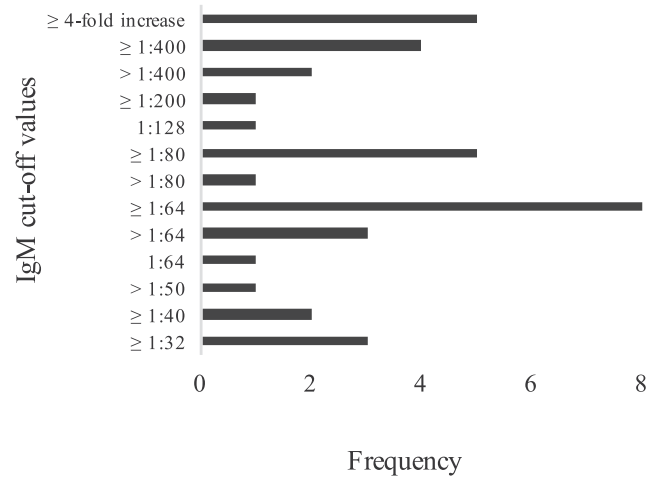

C

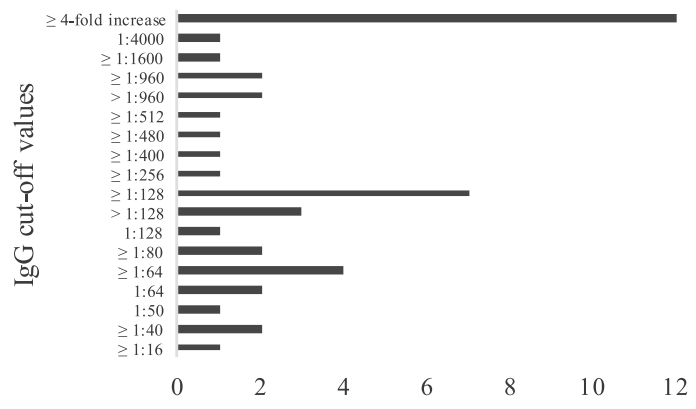

Frequency

FIGURE 1. Diagnostic cutoff values' frequency. (A) The diagnostic cutoff values observed in all the studies included in this review were compiled into this chart. The frequency of each cutoff value is shown. The lowest frequency observed was 1 ; the highest frequency observed was 38 . Two studies that described a range of cutoffs were omitted. (B) The diagnostic cutoff values observed for the lgM isotype were compiled. The lowest frequency observed was 1; the highest frequency observed was 8. Two studies that used a range of cutoffs were omitted. (C) The diagnostic cutoff values observed for the IgG isotype were compiled. The lowest frequency observed was 1; the highest frequency observed was 12.

titer of $\geq 1: 400$ in Lao PDR and $\geq 1: 128$ in South America was common (Table 2). This is probably an appropriate estimation for certain parts of Lao PDR and South America, with limited application in other geographic locations. As has been previously established, it is also likely that these cutoffs are not befitting for the locations in which they were being used. ${ }^{41}$

La Scola et al. ${ }^{6}$ were most commonly cited as a justification for IFA and IIP diagnostic cutoffs for the diagnosis of $R$. typhi. The study also suggests that although the IFA is an appropriate diagnostic method in the case of acute infections, it should be "considered a technique for seroepidemiology only in areas where the seroprevalence of the rickettsial disease has already been established." The article emphasizes that the cutoff should be specific for "each rickettsial disease and each area." 6

Many studies used identical cutoffs for $\lg G$ and $\lg M(26.9 \%$, $21 / 78)$, despite the fact that dynamics of the antibody isotypes differ. This should be considered when interpreting test results, as generally on infection, an increase in $\lg M$ is seen, followed by increased levels of IgG. ${ }^{41,42}$

A variety of factors may affect the diagnostic accuracy of IFAs, including the antibody isotype targeted. Differences in IFA single-titer cutoffs were observed in studies where either IgM or lgG were targeted or both IgM and IgG were targeted to apparently increase the accuracy of the test. In general, higher single-titer cutoffs were used for IgG over IgM, whereas no consensus was seen for studies targeting IgM and IgG together (Table 4).

Considering study populations, the use of samples from infected or normal patients and the geographic origin of the patients can influence the consequent diagnostic cutoff. Murine typhus is an important travel-related illness, ${ }^{7}$ and in a few studies, serum samples were collected from various geographic locations, such as Peru, Russia, United States, and Somalia, although there was ambiguity with regard to whether the cutoff was applied to a single population or whether the cutoff was calculated through results from all the populations despite dissimilarities in endemicity. This emphasizes the complexity surrounding murine typhus serology and the lack of consensus. From the data shown here, no single antibody titer can accurately be advised as diagnostic unless preexistent studies have been performed to establish seroprevalence levels in the normal population within a location.

Moreover, in addition to the lack of IFA methodology standardization, there was also a lack of consensus in the reference comparator or "gold standard reference assay" to determine murine typhus diagnostic cutoffs. The absence of standardized methods and validated cutoffs has serious implications for seroepidemiological and clinical research, as well as implications for patients and healthcare workers. Although a lower cutoff would result in increased false-positive 
TABLE 4

Summary of antibody isotype positivity cutoff titer in selected studies

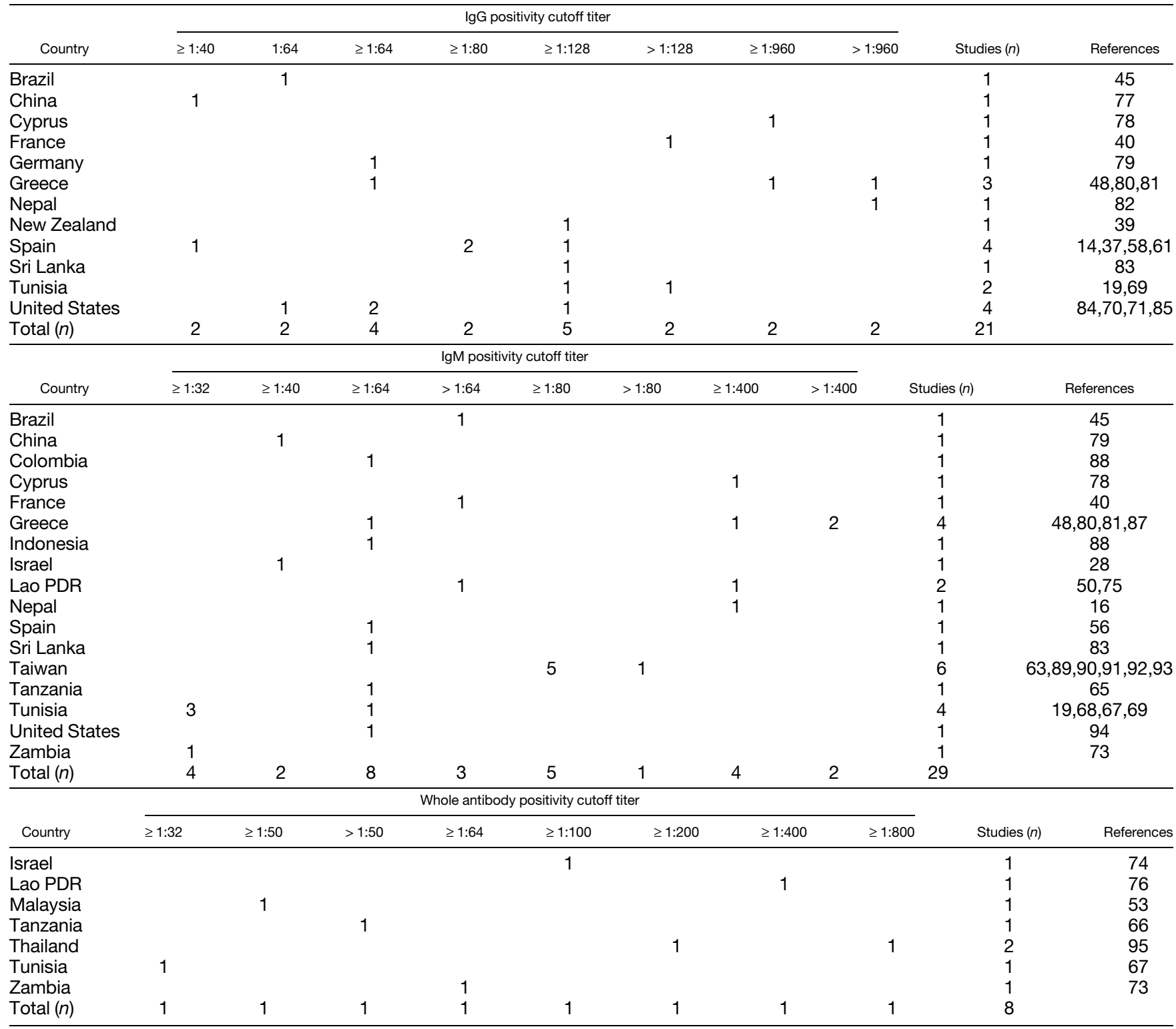

* If the positivity cutoff titer was only seen once, then it was not included on the table.

† Studies performed on travelers were excluded.

results, a higher cutoff would result in increased false-negative results, causing cases to go undiagnosed and increasing the possibility of those patients developing severe complications.

This review has numerous limitations. First, it only investigated studies published in or translated to English. Second, a single author performed the article selection and data extraction, although any ambiguous data were reviewed among the authors to limit bias. Third, the number of diagnostic accuracy studies included was limited, and, perhaps, the study design affects the positivity cutoff titer used for IFA testing. Therefore, it is difficult to conclude whether there exists a correlation or causation between study designs and cutoff titers. Fourth, this review did not consider the timing of serum collection and the collection of paired sera in relation to the disease. The timing of sample collection in relation to illness onset is an important factor to consider when analyzing a positive serological result. Last, the IFA protocol was not assessed as a factor. This is essential to consider when analyzing results, as variances in protocol (i.e., the quantity of antigen used and inactivation techniques) can affect the sensitivity and specificity of IFA tests, which in turn can affect the selection of optimal cutoffs. Moreover, this review examined both IFA and IIP tests, and the two protocols were not differentiated in this study.

From this review, we cannot conclude a single standardized cutoff titer for murine typhus; however, there are some clinical aspects that are important to note. In terms of treatment, murine typhus is treatable with doxycycline, ${ }^{43}$ which is an affordable and safe drug. It is possible to prescribe doxycycline in patients who present with non-malarial febrile illness symptoms; however, it could result in no effect as the patient may be infected with a disease not sensitive to doxycycline. Thus, it is essential to accurately diagnose the disease in patients, for which a validated threshold is needed. In highly 
endemic areas, there are high backgrounds of murine typhus, which poses a potential for false positivity if the cutoff is set too low.

Further research is required to examine the local levels of background immunity, identify circulating antigenic strains, and assess different IFA testing protocols, to make wellversed decisions regarding a region-specific, standardized IFA methodology and cutoff. The prospective cause of fever studies could be carried out in different geographical localities in urban versus rural areas to validate an optimal regionspecific cutoff. Moreover, the timing of serum collection and pairing of sera could be assessed to formulate a criterion to classify confirmed versus probable cases, rather than focus on a single-titer cutoff.

Received November 1, 2019. Accepted for publication February 18, 2020.

Published online April 6, 2020.

Note: Supplemental tables appear at www.ajtmh.org.

Acknowledgments: We thank M. R., J. S., S. G., T. W., P. N., and N. D. for useful discussions and their contributions to this manuscript. We thank the Wellcome Trust of the United Kingdom for providing funding for this study.

Financial support: S. D. B., M. T. R., T. W., P. N. N. and N. P. J. D. are supported by the Wellcome Trust of the United Kingdom.

Authors' addresses: Sandhya Dhawan, Matthew T. Robinson, and Tri Wangrangsimakul, Mahidol Oxford Tropical Medicine Research Unit, Faculty of Tropical Medicine, Mahidol University, Bangkok, Thailand, E-mails: matthew.r@tropmedres.ac, tri@tropmedres.ac, and stuart@ tropmedres.ac. John Stenos, Stephen R. Graves, and Stephen R. Graves, Australian Rickettsial Reference Laboratory, University Hospital Geelong, Geelong, Australia, E-mails: johns@barwonhealth.org.au and graves.rickettsia@gmail.com. Paul N. Newton and Nicholas P. J. Day, Centre for Tropical Medicine and Global Health, Nuffield Department of Medicine, University of Oxford, Oxford, United Kingdom, E-mails: paul.newton@tropmedres.ac and nickd@tropmedres.ac.

This is an open-access article distributed under the terms of the Creative Commons Attribution (CC-BY) License, which permits unrestricted use, distribution, and reproduction in any medium, provided the original author and source are credited.

\section{REFERENCES}

1. Maurin MRD, 2010. Rickettsia typhi (Murine Typhus). Available at: http://www.antimicrobe.org/r06.asp\#r8. Accessed May 15, 2019.

2. Peniche Lara G, Dzul-Rosado KR, Zavala Velazquez JE, ZavalaCastro J, 2012. Murine typhus: clinical and epidemiological aspects. Colomb Med (Cali) 43: 175-180.

3. Civen R, Ngo V, 2008. Murine typhus: an unrecognized suburban vectorborne disease. Clin Infect Dis 46: 913-918.

4. Azad AF, 1990. Epidemiology of murine typhus. Annu Rev Entomol 35: 553-569.

5. Carter CN, Ronald NC, Steele JH, Young E, Taylor JP, Russell LH Jr., Eugster AK, West JE, 1997. Knowledge-based patient screening for rare and emerging infectious/parasitic diseases: a case study of brucellosis and murine typhus. Emerg Infect Dis 3: 73-76

6. La Scola B, Raoult D, 1997. Laboratory diagnosis of rickettsioses: current approaches to diagnosis of old and new rickettsial diseases. J Clin Microbiol 35: 2715-2727.

7. Boyd AS, 1997. Rickettsialpox. Dermatol Clin 15: 313-318.

8. Kelly DJ, Chan CT, Paxton H, Thompson K, Howard R, Dasch GA, 1995. Comparative evaluation of a commercial enzyme immunoassay for the detection of human antibody to Rickettsia typhi. Clin Diagn Lab Immunol 2: 356-360.

9. Philip RN, Casper EA, Ormsbee RA, Peacock MG, Burgdorfer W, 1976. Microimmunofluorescence test for the serological study of rocky mountain spotted fever and typhus. J Clin Microbiol 3: 51-61.

10. Paris DH, Dumler JS, 2016. State of the art of diagnosis of rickettsial diseases: the use of blood specimens for diagnosis of scrub typhus, spotted fever group rickettsiosis, and murine typhus. Curr Opin Infect Dis 29: 433-439.

11. Suto T, 1991. A ten years experience on diagnosis of rickettsial diseases using the indirect immunoperoxidase methods. Acta Virol 35: 580-586.

12. Walter G, Botelho-Nevers E, Socolovschi C, Raoult D, Parola P, 2012. Murine typhus in returned travelers: a report of thirty-two cases. Am J Trop Med Hyg 86: 1049-1053.

13. La Scola B, Rydkina L, Ndihokubwayo JB, VeneS, Raoult D, 2000. Serological differentiation of murine typhus and epidemic typhus using cross-adsorption and Western blotting. Clin Diagn Lab Immunol 7: 612-616.

14. Lledo L, Gegúndez MI, Saz JV, Beltran M, 2001. Prevalence of antibodies to Rickettsia typhi in an area of the center of Spain. Eur J Epidemiol 17: 927-928.

15. Meskini M, Beati L, Benslimane A, Raoult D, 1995. Seroepidemiology of rickettsial infections in Morocco. Eur J Epidemiol 11: 655-660.

16. Blacksell SD, Bryant NJ, Paris DH, Doust JA, Sakoda Y, Day NP, 2007. Scrub typhus serologic testing with the indirect immunofluorescence method as a diagnostic gold standard: a lack of consensus leads to a lot of confusion. Clin Infect Dis 44: 391-401.

17. Coleman RE et al., 2002. Comparative evaluation of selected diagnostic assays for the detection of IgG and IgM antibody to Orientia tsutsugamushi in Thailand. Am J Trop Med Hyg 67: 497-503.

18. Hernandez Cabrera M, Angel-Moreno A, Santana E, Bolaños M, Francès A, Martín-Sánchez MS, Pérez-Arellano JL, 2004. Murine typhus with renal involvement in Canary Islands, Spain. Emerg Infect Dis 10: 740-743.

19. Angelakis E, Botelho E, Socolovschi C, Sobas CR, Piketty C, Parola P, Raoult DS, 2010. Murine typhus as a cause of FeverFin travelers from Tunisia and mediterranean areas. J Travel Med 17: 310-315.

20. Babalis T, Dupont HT, Tselentis Y, Chatzichristodoulou C, Raoult D, 1993. Rickettsia conorii in Greece: comparison of a microimmunofluorescence assay and western blotting for seroepidemiology. Am J Trop Med Hyg 48: 784-792.

21. Tissot Dupont H, Raoult D, Brouqui $P$, Janbon F, Peyramond D, Weiller PJ, Chicheportiche C, Nezri M, Poirier R, 1992. Epidemiologic features and clinical presentation of acute $Q$ fever in hospitalized patients: 323 French cases. Am J Med 93: 427-434.

22. Brown AE, Meek SR, Maneechai N, Lewis GE, 1988. Murine typhus among Khmers living at an evacuation site on the ThaiKampuchean border. Am J Trop Med Hyg 38: 168-171.

23. Chaniotis B, Psarulaki A, Chaliotis G, Gozalo Garcia G, Gozadinos T, Tselentis Y, 1994. Transmission cycle of murine typhus in Greece. Ann Trop Med Parasitol 88: 645-647.

24. Tselentis Y, Babalis TL, Chrysanthis D, Gikas A, Chaliotis G, Raoult D, 1992. Clinicoepidemiological study of murine typhus on the Greek island of Evia. Eur J Epidemiol 8: 268-272.

25. Eremeeva ME, Balayeva NM, Raoult D, 1994. Serological response of patients suffering from primary and recrudescent typhus: comparison of complement fixation reaction, Weil-Felix test, microimmunofluorescence, and immunoblotting. Clin Diagn Lab Immunol 1: 318-324.

26. Ormsbee R, Peacock M, Philip R, Casper E, Plorde J, GabreKidan T, Wright L, 1977. Serologic diagnosis of epidemic typhus fever. Am J Epidemiol 105: 261-271.

27. Fournier PE, Jensenius M, Laferl H, Vene S, Raoult D, 2002. Kinetics of antibody responses in Rickettsia africae and Rickettsia conorii infections. Clin Diagn Lab Immunol 9: 324-328.

28. Gross EM, Arbeli Y, Bearman JE, Yagupsky P, Cohar K, Torok V, Goldwasser RA, 1984. Spotted fever and murine typhus in the Negev desert region of Israel, 1981. Bull World Health Organ 62: 301-306.

29. Fournier PE, Marrie TJ, Raoult D, 1998. Diagnosis of $Q$ fever. J Clin Microbiol 36: 1823-1834. 
30. Brouqui P, Stein A, Dupont HT, Gallian P, Badiaga S, Rolain JM, Mege JL, La Scola B, Berbis P, Raoult D, 2005. Ectoparasitism and vector-borne diseases in 930 homeless people from Marseilles. Medicine (Baltimore) 84: 61-68.

31. Parola P, Miller RS, McDaniel P, Telford SR 3rd, Rolain JM, Wongsrichanalai C, Raoult D, 2003. Emerging rickettsioses of the Thai-Myanmar border. Emerg Infect Dis 9: 592-595.

32. Shirai A, Dietel JW, Osterman JV, 1975. Indirect hemagglutination test for human antibody to typhus and spotted fever group rickettsiae. J Clin Microbiol 2: 430-437.

33. Brown GW, Shirai A, Rogers C, Groves MG, 1983. Diagnostic criteria for scrub typhus: probability values for immunofluorescent antibody and proteus OXK agglutinin titers. Am J Trop Med Hyg 32: 1101-1107.

34. Strickman D, Smith CD, Corcoran KD, Ngampochjana M, Watcharapichat $P$, Phulsuksombati $D$, Tanskul $P$, Dasch GA, Kelly DJ, 1994. Pathology of Rickettsia tsutsugamushi in Bandicota savilei, a natural host in Thailand. Am J Trop Med Hyg 51: 416-423.

35. Gispen R, Gan KH, Westermann CD, 1951. Endemic typhus in Java. I. Incidence and distribution of shop typhus. Documenta Neerlandica et Indonesica de Morbis Tropicis, Vol. 3, 60-66.

36. Newhouse VF, Shepard CC, Redus MD, Tzianabos T, McDade JE, 1979. A comparison of the complement fixation, indirect fluorescent antibody, and microagglutination tests for the serologic diagnosis of rickettsial diseases. Am J Trop Med Hyg 28: 387-395.

37. Bolanos-Rivero $M$, Santana-Rodriguez E, Angel-Moreno $A$, Hernández-Cabrera M, Limiñana-Canal JM, CarranzaRodríguez C, Martín-Sánchez AM, Pérez-Arellano JL, 2011. Seroprevalence of Rickettsia typhi and Rickettsia conorii infections in the Canary Islands (Spain). Int $J$ Infect Dis 15: e481-e485.

38. Chen MI, Chua JK, Lee CC, Leo YS, Kumarasinghe G, 2001. Epidemiological, clinical and laboratory characteristics of 19 serologically confirmed rickettsial disease in Singapore. Singapore Med J 42: 553-558.

39. Lim MY, Weinstein P, Bell A, Hambling T, Tompkins DM, Slaney D, 2016. Seroprevalence of antibodies to Rickettsia typhi in the Waikato region of New Zealand. Epidemiol Infect 144: 2283-2289.

40. Balleydier E et al., 2015. Murine typhus, reunion, France, 2011-2013. Emerg Infect Dis 21: 316-319.

41. Saraswati K, Phanichkrivalkosil M, Day NPJ, Blacksell SD, 2019. The validity of diagnostic cut-offs for commercial and in-house scrub typhus IgM and IgG ELISAs: a review of the evidence. PLoS Negl Trop Dis 13: e0007158.

42. Phakhounthong K, Mukaka M, Dittrich S, Tanganuchitcharnchai A, Day NPJ, White LJ, Newton PN, Blacksell SD, 2019. The temporal dynamics of humoral immunity to Rickettsia typhi infection in murine typhus patients. Clin Microbiol Infect. https:// doi.org/10.1016/j.cmi.2019.10.022.

43. Newton PN et al., 2019. A prospective, open-label, randomized trial of doxycycline versus azithromycin for the treatment of uncomplicated murine typhus. Clin Infect Dis 68: 738-747.

44. Lau C, Musso D, Fournier PE, Parola P, Raoult D, Weinstein P, 2016. Absence of serological evidence of Rickettsia spp., Bartonella spp., Ehrlichia spp. and Coxiella burnetii infections in American Samoa. Ticks Tick Borne Dis 7: 703-705.

45. da Costa PS, Brigatte ME, Greco DB, 2005. Antibodies to Rickettsia rickettsii, Rickettsia typhi, Coxiella burnetii, Bartonella henselae, Bartonella quintana, and Ehrlichia chaffeensis among healthy population in Minas Gerais, Brazil. Mem Inst Oswaldo Cruz 100: 853-859.

46. Dobec M, Dzelalija B, Punda-Polic V, Zoric I, 2006. High prevalence of antibodies to lymphocytic choriomeningitis virus in a murine typhus endemic region in Croatia. $J$ Med Virol 78: 1643-1647.

47. Gray GC, Rodier GR, Matras-Maslin VC, Honein MA, Ismail EA, Botros BA, Soliman AK, Merrell BR, Wang SP, Grayston JT, 1995. Serologic evidence of respiratory and rickettsial infections among Somali refugees. Am J Trop Med Hyg 52: 349-353.
48. Daniel SA, Manika K, Arvanmdou M, Antoniadis A, 2002. Prevalence of Rickettsia conorii and Rickettsia typhi infections in the population of northern Greece. Am J Trop Med Hyg 66: 76-79.

49. Van Peenen PF, Koesharjono C, See R, Bourgeois AL, Irving GS, 1977. Antibodies against murine typhyus in sera from Indonesians. Trans R Soc Trop Med Hyg 71: 297-299.

50. Phongmany $S$ et al., 2006. Rickettsial infections and fever, Vientiane, Laos. Emerg Infect Dis 12: 256-262.

51. Rakotonanahary RJ, Harrison A, Maina AN, Jiang J, Richards AL, Rajerison M, Telfer S, 2017. Molecular and serological evidence of flea-associated typhus group and spotted fever group rickettsial infections in Madagascar. Parasit Vectors 10: 125.

52. Strickman D, Tanskul P, Eamsila C, Kelly DJ, 1994. Prevalence of antibodies to rickettsiae in the human population of suburban Bangkok. Am J Trop Med Hyg 51: 149-153.

53. Tay ST, Ho TM, Rohani MY, Devi S, 2000. Antibodies to Orientia tsutsugamushi, Rickettsia typhi and spotted fever group rickettsiae among febrile patients in rural areas of Malaysia. Trans $R$ Soc Trop Med Hyg 94: 280-284.

54. Blacksell SD, Sharma NP, Phumratanaprapin W, Jenjaroen K, Peacock SJ, White NJ, Pukrittayakamee S, Day NP, 2007. Serological and blood culture investigations of Nepalese fever patients. Trans $R$ Soc Trop Med Hyg 101: 686-690.

55. Nogueras MM, Pons I, Sanfeliu I, Sala M, Segura F, 2014. Serosurvey of Rickettsia typhi and Rickettsia felis in HIVinfected patients. Microbiol Immunol 58: 257-259.

56. Santibanez S, Astasio A, Villa-Real R, Camara JA, Oteo JA, Marquez FJ, 2009. Serologic study of Rickettsia typhi infection among the human population of southern Spain. Clin Microbiol Infect 15 (Suppl 2): 247-248.

57. Bernabeu-Wittel M, Canas Garcia-Otero E, Herrero Romero M, Ordóñez Fernández A, Martínez Martínez A, Pérez Bernal J, Cisneros Herreros JM, 1999. Infectious complications of heart transplantation. A prospective study for the first 6 years of a transplantation program. Rev Clin Esp 199: 489-495.

58. Nogueras MM, Cardenosa N, Sanfeliu I, Munoz T, Font B, Segura $\mathrm{F}, 2006$. Evidence of infection in humans with Rickettsia typhi and Rickettsia felis in Catalonia in the Northeast of Spain. Ann N Y Acad Sci 1078: 159-161.

59. Ruiz-Beltran R, Herrero-Herrero Jl, Martin-Sanchez AM, MartinGonzalez JA, 1990. Prevalence of antibodies to Rickettsia conorii Coxiella burnetii and Rickettsia typhi in Salamanca province (Spain). Serosurvey in the human population. Eur $J$ Epidemiol 6: 293-299.

60. Bernabeu-Wittel M, del Toro MD, Nogueras MM, Muniain MA, Cardeñosa N, Márquez FJ, Segura F, Pachón J, 2006. Seroepidemiological study of Rickettsia felis, Rickettsia typhi, and Rickettsia conorii infection among the population of southern Spain. Eur J Clin Microbiol Infect Dis 25: 375-381.

61. Lledo L, Gegundez MI, Medina J, Gonzalez JV, Alamo R, Saz JV, 2005. Epidemiological study of Rickettsia typhi infection in two provinces of the north of Spain: analysis of sera from the general population and sheep. Vector Borne Zoonotic Dis 5: 157-161.

62. Nogueras MM, Cardenosa N, Sanfeliu I, Munoz T, Font B, Segura F, 2006. Serological evidence of infection with Rickettsia typhi and Rickettsia felis among the human population of Catalonia, in the northeast of Spain. Am J Trop Med Hyg 74: 123-126.

63. Lai CH, Huang CK, Chen YH, Chang LL, Weng HC, Lin JN, Chung $\mathrm{HC}$, Liang SH, Lin HH, 2009. Epidemiology of acute q Fever, scrub typhus, and murine typhus, and identification of their clinical characteristics compared to patients with acute febrile illness in southern Taiwan. J Formos Med Assoc 108: 367-376.

64. Lai $\mathrm{CH}$ et al., 2017. The epidemiology and characteristics of $Q$ fever and co-infections with scrub typhus, murine typhus or leptospirosis in taiwan: a nationwide database study. Zoonoses Public Health 64: 517-526.

65. Prabhu M et al., 2011. Q fever, spotted fever group, and typhus group rickettsioses among hospitalized febrile patients in northern Tanzania. Clin Infect Dis 53: e8-e15.

66. Anstey NM, Tissot Dupont H, Hahn CG, Mwaikambo ED, McDonald MI, Raoult D, Sexton DJ, 1997. Seroepidemiology of Rickettsia typhi, spotted fever group rickettsiae, and Coxiella burnetti infection in pregnant women from urban Tanzania. Am J Trop Med Hyg 57: 187-189. 
67. Letaief AO, Yacoub S, Dupont HT, Le Cam C, Ghachem L, Jemni L, Raoult D, 1995. Seroepidemiological survey of rickettsial infections among blood donors in central Tunisia. Trans $R$ Soc Trop Med Hyg 89: 266-268.

68. Kaabia N, Rolain JM, Khalifa M, Ben Jazia E, Bahri F, Raoult D, Letaïef $A, 2006$. Serologic study of rickettsioses among acute febrile patients in central Tunisia. Ann N Y Acad Sci 1078: 176-179.

69. Znazen A, Hammami B, Mustapha AB, Chaari S, Lahiani D, Maaloul I, Jemaa MB, Hammami A, 2013. Murine typhus in Tunisia: a neglected cause of fever as a single symptom. Med Mal Infect 43: 226-229.

70. Comer JA, Diaz T, Vlahov D, Monterroso E, Childs JE, 2001. Evidence of rodent-associated Bartonella and Rickettsia infections among intravenous drug users from central and East Harlem, New York city. Am J Trop Med Hyg 65: 855-860.

71. Purcell K, Fergie J, Richman K, Rocha L, 2007. Murine typhus in children, south Texas. Emerg Infect Dis 13: 926-927.

72. Hamaguchi $\mathrm{S}$ et al., 2015. Clinical and epidemiological characteristics of scrub typhus and murine typhus among hospitalized patients with acute undifferentiated fever in northern Vietnam. Am J Trop Med Hyg 92: 972-978.

73. Okabayashi T, Hasebe F, Samui KL, Mweene AS, Pandey SG, Yanase T, Muramatsu Y, Ueno H, Morita C, 1999. Short report: prevalence of antibodies against spotted fever, murine typhus, and $Q$ fever rickettsiae in humans living in Zambia. Am J Trop Med Hyg 61: 70-72.

74. Keysary A, Strenger C, 1997. Use of enzyme-linked immunosorbent assay techniques with cross-reacting human sera in diagnosis of murine typhus and spotted fever. J Clin Microbio/ 35 : 1034-1035.

75. Blacksell SD, Jenjaroen K, Phetsouvanh R, Tanganuchitcharnchai A, Phouminh P, Phongmany S, Day NP, Newton PN, 2010. Accuracy of rapid IgM-based immunochromatographic and immunoblot assays for diagnosis of acute scrub typhus and murine typhus infections in Laos. Am J Trop Med Hyg 83: 365-369.

76. Phetsouvanh R, Thojaikong T, Phoumin P, Sibounheuang B, Phommasone K, Chansamouth V, Lee SJ, Newton PN, Blacksell SD, 2013. Inter- and intra-operator variability in the reading of indirect immunofluorescence assays for the serological diagnosis of scrub typhus and murine typhus. Am J Trop Med Hyg 8: 932-936.

77. Yang WH et al., 2012. Murine typhus in drug detoxification facility, Yunnan province, China, 2010. Emerg Infect Dis 18: 1388-1390.

78. Koliou M, Psaroulaki A, Georgiou C, loannou I, Tselentis Y, Gikas A, 2007. Murine typhus in Cyprus: 21 paediatric cases. Eur $J$ Clin Microbiol Infect Dis 26: 491-493.

79. Rauch J, Eisermann P, Noack B, Mehlhoop U, Muntau B, Schäfer J, Tappe D, 2018. Typhus group rickettsiosis, Germany, 2010-2017 ${ }^{1}$. Emerg Infect Dis 24: 1213-1220.

80. Chaliotis G, Kritsotakis El, Psaroulaki A, Tselentis Y, Gikas A, 2012. Murine typhus in central Greece: epidemiological, clini$\mathrm{cal}$, laboratory, and therapeutic-response features of 90 cases. Int J Infect Dis 16: e591-e596.
81. Tsioutis C, Chaliotis G, Kokkini S, Doukakis S, Tselentis $\mathrm{Y}$, Psaroulaki A, Gikas A, 2014. Murine typhus in elderly patients: a prospective study of 49 patients. Scand J Infect Dis 46: 779-782.

82. Thompson $\mathrm{CN}$ et al., 2015. Undifferentiated febrile illness in Kathmandu, Nepal. Am J Trop Med Hyg 92: 875-878.

83. Angelakis $E$ et al., 2012. Detection of rickettsioses and $Q$ fever in Sri Lanka. Am J Trop Med Hyg 86: 711-712.

84. Blanton LS, Vohra RF, Bouyer DH, Walker DH, 2015. Reemergence of murine typhus in Galveston, Texas, USA, 2013. Emerg Infect Dis 21: 484-486.

85. Dumler JS, Taylor JP, Walker DH, 1991. Clinical and laboratory features of murine typhus in south Texas, 1980 through 1987. JAMA 266: 1365-1370.

86. Hidalgo $M$, Salguero $E$, de la Ossa A, Sánchez R, Vesga JF, Orejuela L, Valbuena G, 2008. Murine typhus in Caldas, Colombia. Am J Trop Med Hyg 78: 321-322.

87. Gikas A, Kokkini S, Tsioutis C, Athenessopoulos D, Balomenaki E, Blasak S, Matheou C, Tselentis Y, Psaroulaki A, 2009. Murine typhus in children: clinical and laboratory features from 41 cases in Crete, Greece. Clin Microbiol Infect 15: 211-212.

88. Gasem MH, Wagenaar JF, Goris MG, Adi MS, Isbandrio BB, Hartskeerl RA, Rolain JM, Raoult D, van Gorp EC, 2009. Murine typhus and leptospirosis as causes of acute undifferentiated fever, Indonesia. Emerg Infect Dis 15: 975-977.

89. Chang $\mathrm{K}$ et al., 2012. Murine typhus in southern Taiwan during 1992-2009. Am J Trop Med Hyg 87: 141-147.

90. Chang K, Lee NY, Ko WC, Lin WR, Chen YH, Tsai JJ, Chen TC, Lin CY, Chang YT, Lu PL, 2019. Characteristics of scrub typhus, murine typhus, and $Q$ fever among elderly patients: prolonged prothrombin time as a predictor for severity. J Microbiol Immunol Infect 52: 54-61.

91. Chang K, Lee NY, Ko WC, Tsai JJ, Lin WR, Chen TC, Lu PL, Chen $\mathrm{YH}, 2017$. Identification of factors for physicians to facilitate early differential diagnosis of scrub typhus, murine typhus, and Q fever from dengue fever in Taiwan. J Microbiol Immunol Infect 50: 104-111.

92. Lai $\mathrm{CH}$, Huang $\mathrm{CK}$, Weng $\mathrm{HC}$, Chung HC, Liang $\mathrm{SH}$, Lin JN, Lin $\mathrm{CW}$, Hsu CY, Lin HH, 2008. Clinical characteristics of acute Q fever, scrub typhus, and murine typhus with delayed defervescence despite doxycycline treatment. Am J Trop Med Hyg 79: 441-446.

93. Lai CH, Chang LL, Lin JN, Tsai KH, Hung YC, Kuo LL, Lin HH, $\mathrm{Chen} \mathrm{YH}, 2014$. Human spotted fever group rickettsioses are underappreciated in southern Taiwan, particularly for the species closely-related to Rickettsia felis. PLoS One 9: e95810.

94. Rawlings JA, Elliott LB, Little LM, 1985. Comparison of a latex agglutination procedure with the microimmunofluorescence test for Rickettsia typhi. J Clin Microbiol 21: 470-471.

95. Duffy PE, Le Guillouzic H, Gass RF, Innis BL, 1990. Murine typhus identified as a major cause of febrile illness in a camp for displaced Khmers in Thailand. Am J Trop Med Hyg 43: 520-526. 